\title{
Between Stalin and Dionysus: Bakhtin's Theory of the Carnival $^{1}$
}

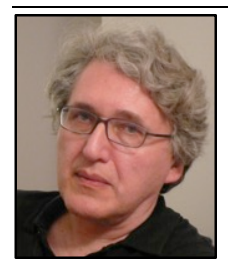

Boris Groys

New York University, US

\section{Abstract}

The essay by Russian American philologist Boris Groys and nine commentaries followed by Groys' reply to them in this special issue: "Deconstructing Bakhtin, Carnival with Evil", present a provocative discussion about Bakhtin's conceptual work and legacy for education and beyond. Boris Groys argued that Bakhtin embraced a dangerous play with Stalin's totalitarianism through fusing art and life, prioritizing cosmic carnival over human rights and by being mesmerised by dionysian passions. The following nine commentaries, written by educationalists and noneducationalists, present a diverse spectrum of reactions to Groys' criticism of Bakhtin: from passionate rejections to sympathetic acceptance seriously considering implications of Groys' charges. The biggest implication for education is the relationship between the teacher and the student, specifically whether the teacher authors the student and the student's education or not. The first commentary, written by Caryl Emerson provides a brilliant overview of all these diverse positions, in education and beyond. - DPJ Editors: Eugene Matusov and Ana Marjanovic-Shane

Boris Groys, Professor of Russian and Slavic Studies, NYU and Professor of Philosophy and Art Theory, European Graduate School, Switzerland.

$\cos 8000$

The postmodern, or, more exactly, poststructuralist, theorizing of 1970-1980s was mostly fed by the ideas and trends of the late 1920s - 1930s that emerged due to the crisis of the avant-garde movement. In the 1930s the faith in the truthfulness and saving grace of new avant-garde revelations had already been lost, but at the same time, the break up with the tradition that occurred during the avantgarde period was recognized as final and irreversible. As a result, the traditional emphasis on the ideals of objectivity, rationality, and scientism was questioned to the same degree as the avant-garde emphasis on authenticity, intuition, originality, and novelty. An individual of the 1920 s - 1930s began to identify himself $^{2}$ as an integral part of the material world, from which he could not distance himself either by contemplating and investigating it or by clamming up in his own inner world. However, the world could still reveal itself to this individual at the extremes of his own material, physical existence - through the reality of death and Eros, in the totality of the worldly power or in the extreme situations demanding superhuman exertion of the person's whole being.

\footnotetext{
${ }^{1}$ First published in Russian, "Mezhdu Stalinym i Dionisom" (Between Stalin and Dionysus), Sintaxis, 25, Paris, 1989, pp. 92-98. The current text is translated from the Russian version, Groys B., (1997), Totalitarianism of carnival (pp. 76-80). In V. L. Makhlin (Ed), Bakhtinian collection, issue 3, Moscow: Labirint by Yury Almetev, checked and edited by the author, Boris Groys.

${ }^{2}$ In Russian, the gender of pronouns often refers to the three genders of nouns: masculine, feminine, and neutral.
} 
Obviously, the postmodern philosophy, traditionally associated with such French authors as Jacques Derrida, Jacques Lacan, and Gilles Deleuze, does not put much trust in the possibility of understanding the world in its "borderline situations," because it believes that the very notion that the world's borderlines can be experientially grasped is rooted in the traditional "metaphysical" idea of acquiring a "metaposition" in relation to the world in its entirety. In this respect, the accusation that postmodernism resurrected the politically compromised ideologies of the 1930s has absolutely no grounds: on the contrary, the postmodern theory is directed against all kinds of purely philosophical totalism and political totalitarianism as well. At the same time, the postmodern theory uses the argumentation from that era of "super-realism" (an apt name for the 1930s with their social realism, surrealism, magic realism, etc.) against modernist illusions, which underwent a robust restoration after the World War II on the wave of a purely emotional compassion towards the ideals of modernism, persecuted by totalitarian regimes. At the same time, those very modernist illusions, which were partially preserved and even radicalized in the 1930s, led, in the opinion of modern French philosophers, to the ensuing disasters: the politico-moral intentions of the postmodern theory are obviously quite decent; - the confusion emerges only because of the problems that the diagnosis of the previous period of philosophical development presents.

At the same time, both the total initial condemnation and, later, the postmodern well-intentioned interpretation of super-realism of the 1930s equally share in obscuring its real historical outline. The symptoms of dissatisfaction with this state of affairs can be seen in the current discussion of the political implications of Heidegger's philosophy and new publications on the political flirting and affiliations of French surrealists with and their maneuvers between Fascism, Stalinism, and Trotskyism. In this context, the figure of the Russian theorist of culture Mikhail Bakhtin is especially relevant. His major works also date back to the late 1920s - 1930s, they fit quite well into the paradigm of super-realism mentioned above, and they have played an important role in the development of postmodern theory - especially in France and the USA.

Bakhtin is known, first and foremost, as the theorist of the "polyphonic novel" and as a theorist of "carnival." Both theories have been elaborated by him as his commentaries to novels, the former as a commentary to Dostoyevsky's novels, and the latter to Rabelais' "Gargantua and Pantagruel." Influenced by Marx and Freud, and even more so by Nietzsche, Bakhtin negatively reacts to the Russian avantgardist formalist theory, proclaiming an author's supreme control over the material of his or her artistic work, or the principle of "madeness" of an artwork. In the avant-gardist emphasis on the author, Bakhtin saw the perpetuation of the traditional "monologism", as it is represented by the privileged position of the author's voice in the narration. For Bakhtin, each word is just a remark in the endless dialogue of everyone with everyone else: it is always originally passive, separated from the speaker, contains in itself the reduced voices of "others" - and this is also true about the author's voice. Not only does the word [i.e., discourse], as a material "body of the thought," lack independence, autonomy and authenticity, similarly, the actual human body is also a part of the whole, universal, world's "grotesque body." Through its boundaries and apertures, the human body is united with the world's matter, world's metabolism, and world's Eros, which manifest themselves in the carnival that disrupts a person's autonomy, removes its everyday untouchability, and dismantles its usual protective Habeas corpus act. A "polyphonic novel" transcends individual authorship and, therefore, is rooted, according to Bakhtin, in carnival, which refutes all individualization: a "polyphonic novel" is interpreted by Bakhtin as a result of "carnivalization of literature." This means the destruction of the isolation, independence, and individuality of the word and the removal of the author's rights to private discourse diffused in the general polyphony of the language, which belongs collectively to the "people." Bakhtin's theory, in fact, equates literature to life - and, therefore, it invites its reader to see this theory as a life program formulated in what can be called Aesop's 
language. Hence a question arises about the political implications of Bakhtin's thought, a topic, which has been recently debated by many researchers. In the absolute majority of interpretations, Bakhtin's "polyphony" is understood as a protest against the "monologism" of Stalin's ideology, of which he was a contemporary, whereas "carnivalization" is understood as a reaction to the impeccably serious and strict tone of the official Soviet institutions of that period. Bakhtin, therefore, becomes a mouthpiece of the democratic, genuinely people's alternative to the hierarchically organized totalitarian state - the sole thinker of the Soviet period who remained loyal to the utopian idea of the united, truly "people's" life. The only existing criticism to Bakhtin is the observation that carnival, with all its "revolutionary potential," still fits into the traditional, hierarchical order, and even, at the end of the day, legitimizes and enforces the latter by providing a controlled vent for people's dissatisfaction. However, taking into consideration the censorship burden of that time, this "not being revolutionary enough" is usually forgiven to Bakhtin, so he keeps his halo of a consistently anti-totalitarian thinker.

At the same time, if there is something Bakhtin insists upon, then it is this totality of carnival, which destroys and absorbs each individual body: for Bakhtin, carnival is first and foremost a manifestation of the belonging to the folk (narodnost'). The belonging to the folk was, by the way, the characteristic core of the Stalinist culture, which followed the period of avant-gardist "belonging to the class" (classovost')). Bakhtin's attitude to liberalism and democracy in their traditional meaning is that of deep antipathy: for him, they are synonymous to alienation, autonomization, clamming up of individuality, the separation of the latter from the natural unity of cosmic and people's life - and, consequently, they become the historical reasons for the emergence of the pathos of seriousness, sentimentality, moralizing, and, also, of the devolution of the people's carnivalesque laughter into individualistic criticism and satire. It is in jubilant expressions that Bakhtin refers to the Rabelaisian descriptions of atrocious carnival battles, stoning people with "funny matter" (feces) and splashing them with urine, the rituals of carnival insults, "dethroning and crowning," the images of the triumphal carnivalesque Death, symbolizing people's joy about the "demise of everything obsolete and already dead"

Bakhtin welcomes the carnivalesque pathos of the "final death" of everything individual and the victory of the purely material, bodily principle over everything transcendental, ideal, individually immortal. Simply put, Bakhtin's carnival is horrible - God forbid being part of it. There is no place for democracy in it - nobody is given the democratic right to avoid the total carnival duty, to abscond the carnival, to stay away from it. On the contrary, those who try to do so are the first to be subjected to "funny insults and beatings." All this grotesque horror, according to Bakhtin, turns into a joyful carnival thanks to people's continuous laughter, by which it is surrounded. But the carnivalesque laughter has nothing to do with the philosopher's irony over the tragedy of life - it is the boisterous laughter of people's, or cosmic, "bodily" idiocy over the suffering agony of a tormented individual, who looks ridiculous in his lonesome helplessness. This laughter emerges from the primitive belief that a "people" is something quantitatively and materially larger than an individual, whereas the world is something larger than a people, which is, after all, the belief in the ultimate truth of totalitarianism ${ }^{4}$.

\footnotetext{
${ }^{3}$ DPJ editors: This seems to be Groys' loose quotation of Bakhtin, "The death of the old world and the merriment of the new world are combined in this system of images. The bonfire which has consumed the old is transformed into the kitchen hearth. The phoenix is reborn from its ashes" (Bakhtin, 1984, p. 210).

${ }^{4}$ In this sense it is interesting to note the relationship of Bakhtin's carnival to the concept of Gesamtkunstwerk that was developed by famous German composer Richard Wagner in his "Artwork of the Future." Gesamtkunstwerk is precisely the art event that embraces the whole Folk and has the polyphonic structure. Wagner notes: "The last, completest renunciation (Entäusserung) of his personal egoism, the demonstration of his full ascent into universalism, a man can only show us by his Death; and that not by his accidental, but by his necessary death, the logical sequel to his actions, the last fulfillment of his being. The celebration of such a death is the noblest thing that men can enter on" (Wagner, 1993/1849, p.199). The individual must die in order to establish a communist society. Wagner's analysis of comedy is especially interesting in this regard. The comedy is for him a Gesamtkunstwerk under the conditions of Communism. Here the main hero will be incapable any more to commit an act of self-sacrifice on his own
} 
This truth is, according to Bakhtin, incarnated in the "carnivalesque", or, in other words, "polyphonic" novel. All the voices, in Bakhtin's opinion, have the right to be heard - but only within the context of a whole, totalitarian, all-absorbing novel. Such a novel, in fact, cannot even have an author, because an author should exist outside of the novel - which, according to Bakhtin, is not allowed to anyone. A "polyphonic" novel tautologically reproduces its own total, always proportional to itself, polyphony - just like the carnival always reproduces its own total carnivalesque properties. Consequently, Bakhtin de facto denies the existence of multiple novels with different authors and he accepts only one differentiation in the space of the novel genre, -novels are either monologic and are, therefore, dismissed as too individualistic, or polyphonic, which means they reproduce each other as they reproduce polyphony itself, making, therefore, their author a hypothetical, fictitious figure. For Bakhtin, "other" is always someone inside a novel, and never can it be someone outside of the novel.

Bakhtin's descriptions of the carnival and carnivalization are without a doubt inspired by his experience of the Revolution and Civil War. However, even to a greater extent, they reproduce the atmosphere of Stalin's terror with its unbelievable eulogies and vilifications, and also with its unexpected crownings and dethronings, which obviously had a carnavalesque nature (Stalin himself notoriously said that "life has become more joyous", whereas his favorite Soviet feature film "Volga-Volga" was the purely carnavalesque). There are many accounts of the specific "joyousness" of the 1930s. For example, it is widely known that the show trials and, especially, the verdicts thereof were accompanied by the laughter of the audience. The context of Stalin is also supported by the fact that both the polyphonic novel and carnivalesque act, though being allegedly born in the people's mind, are still directed, according to Bakhtin, by a certain super-author - Dostoyevsky or Rabelais, which obliquely points at the author of the corresponding "life text", which could refer to no one else but Stalin.

All these considerations point at the fact that Bakhtin's aim was not to criticize the Revolution and Stalin's terror from a democratic standpoint, but to theoretically justify them as an archaic, carnevalistic ritual rooted in ancient traditions. Bakhtin's carnival is not, therefore, a representation of a frustrated Revolution that could not fully unfold its potential, but a justification of the absurdity and cruelty of the Revolution, which can be only grasped in the a-historic space of pure and universal laughter. Bakhtin's contemporary researchers still think in the pre-revolution paradigm, whereas Bakhtin himself was a postrevolutionary thinker: Revolution itself could not have much value for him.

Does it all mean then that Bakhtin was a crypto-Stalinist of sorts? And if so, what would be the point of it, considering how much easier it was at that time to just be a regular Stalinist?

Obviously, Bakhtin was not a Stalinist. But he was not an anti-Stalinist either. By his upbringing, friendships, social and cultural backgrounds, Bakhtin belonged to the class of people who became victims of the Revolution and Stalinism - but it was exactly that very circumstance that made it psychologically impossible for him to moralizingly condemn those phenomena: he was too much of a follower of Nietzsche and the Russian Silver $\mathrm{Age}^{6}$ to allow himself to be in a position of protest that could been born out of his personal resentment. The tragedy of Revolution - and his own personal tragedy ${ }^{7}-$ was understood by Bakhtin as a manifestation of the eternal cosmic tragedy, constantly and ritualistically replaying itself, which can and must be "aesthetically justified," in order not to be futile. Bakhtin is not

free will: "The Egoist will be compelled to ascend into Community . . . and, without further breathing-space for his self-seeking, he sees at last his only rescue in the unconditional acknowledgment of its necessity. The artistic Fellowship, as the representative of Generality, will therefore have in Comedy an even director share in the framing of the poem itself, than in Tragedy." (Wagner, p.102, footnote)

${ }^{5}$ Soviet musical comedy produced in 1938, https://en.wikipedia.org/wiki/Volga-Volga

${ }^{6} \mathrm{https}: / /$ en.wikipedia.org/wiki/Silver_Age_of_Russian_Poetry

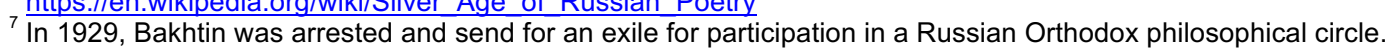


alone in this intention as the aesthetic justification of the era was one of the central themes of the Russian culture of that period. The carnevalistic interpretation of the Stalinist culture is obvious in the novel "Master and Margarita" by Mikhail Bulgakov ${ }^{8}$ but also in the writing of the OBERIU literary circle ${ }^{9}$. In the West the most direct analogies can be found in "Man and the Sacred" by Roger Caillois and "Accursed Share" by Georges Bataille.

The Stalinist Russia was, in fact, interpreted by Bakhtin in the Nietzschean terms of Apollonian and Dionysian forces, customary for the Russian culture beginning from the Silver Age. For Bakhtin, carnival is synonymous to a Dionysian mystery: the victim of the Apollonian Stalinist terror interprets it as an act of a ritualistic Dionysian self-destruction - and, by that, overcomes this terror, changing its meaning from inside and inwardly stopping to be its passive victim. It should be noted, though, that this overcoming of a life tragedy through self-sacrifice is devoid, in Bakhtin's viewpoint, of that ecstatic dissolution in the unconscious and impersonal, which, for Nietzsche, constitutes the main pathos of the Dionysian. For Bakhtin, individuality is radically limited and finite. In carnival, its finitude and mortality, at last, become self-evident. The third, laughing, party is represented by people or cosmos - an individual does not have any other choice in carnival but to accept his own destruction as a positive thing - as selfrebirth and self-renewal.

Bakhtin's example shows that the totalitarian mindset of the 1930s is not at all limited to the dreams of super-human power. Even those who did not cherish the Apollonian illusions of the absolute power over the world could think in the totalitarian paradigm, insofar as they were ready for the Dionysian self-sacrifice, involving the whole totality of the world. This "different" totalitarianism cannot be subjected to the usual ideological criticism, traditionally aimed at revealing the combination of idealism and the will to power, because it represents a combination of materialism and the will to self-sacrifice. A possible criticism of such alternative strategy of totalitarianism puts forward a demand to question the unity not only of the "idealist", or "theoretical", but also of the material, "real" world, which, however, continues to be affirmed in many of its varieties - including, for example, ecology, - even in our postmodern times.

\section{References}

Bakhtin, M. M. (1984). Rabelais and his world (H. Iswolsky, Trans. 1st Midland book ed.). Bloomington: Indiana University Press.

Wagner, Richard, The Art-work of the Future and Other Works, trans. W. Ashton Ellis, University of Nebraska Press, Lincoln 1993/1849.

\section{(cc) EY}

New articles in this journal are licensed under a Creative Commons Attribution 4.0 United States License.

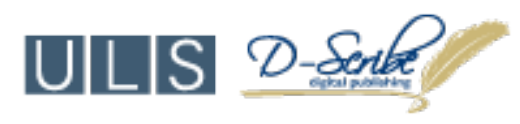

This journal is published by the University Library System, University of Pittsburgh as part of its D-Scribe Digital Publishing Program and is cosponsored by the University of Pittsburgh Press.

\footnotetext{
${ }_{9}^{8}$ https://en.wikipedia.org/wiki/Mikhail_Bulgakov
}

9 https://en.wikipedia.org/wiki/Oberiu 